\title{
DEGRADABILIDADE in vitro DA PROTEÍNA DE ESPÉCIES ARBÓREAS DO SEMI-ÁRIDO BRASILEIRO
}

\section{(In vitro degradability of protein from Brazil semiarid arboreal speccies)}

\author{
SANTOS E.M. ${ }^{1}$; ZANINE, A.M. ${ }^{1}$; OLIVEIRA, J.S. ${ }^{1}$ MANTOVANI, H.C. ${ }^{2}$; \\ FERREIRA, D.J.F.; PEREIRA, O.G. ${ }^{4}$
}

'Doutorando em Zootecnia. Universidade Federal de Viçosa;

${ }^{2}$ Departamento de Microbiologia da UFV;

${ }^{3}$ Graduando em Zootecnia. UFRRJ, Seropédica;

${ }^{4}$ Departamento de Zootecnia da UFV.

\begin{abstract}
RESUMO - O experimento teve como objetivo avaliar a degradabilidade in vitro da proteína de plantas arbóreas do semi-árido brasileiro e do farelo de soja. As plantas utilizadas foram angico (Anadenanthera colubrina), algaroba (Prosopis juliflora), espinheiro (Acacia glomerosa), juazeiro (Ziziphus joazeiro) e o farelo de soja, com valores de proteína bruta de 22,5 $16,0,22,0,19,0$ e $38,0 \%$, respectivamente. Amostras de cada planta $(60 \mathrm{mg})$ foram incubadas em $8 \mathrm{ml}$ de meio tampão de McDougal, com adição de $2 \mathrm{ml}$ de inóculo ruminal. Nos tempos 0, 6, 12, 24, 36 e 48 horas após a incubação foi retirada uma alíquota de 1,0 ml para análise de amônia, proteína solúvel e proteína microbiana. O farelo de soja e a algaroba proporcionaram maiores produção de amônia e concentração de proteína solúvel em relação aos outros alimentos, sendo que o farelo de soja apresentou maior valor de proteína microbiana. O tratamento com o angico foi o que mais se aproximou à soja com relação ao valor de proteína microbiana, apesar da sua menor produção de amônia. O maior valor de degradabilidade potencial $66,47 \%$, foi observado no tratamento com farelo de soja, seguidos dos tratamentos da algaroba $46,27 \%$ e angico $45,20 \%$. Foram observados valores de degradabilidade muito baixos para o espinheiro e juazeiro, 19,16 e 16,63\%, respectivamente. O angico e a algaroba apresentaram-se como melhores fontes de proteína entre as plantas avaliadas.
\end{abstract}

Palavras-chaves: algaroba, angico, espinheiro, juazeiro.

ABSTRACT - This experiment was carried out to evaluate the protein degradability in vitro of arboreal plants from Brazilian semi-arid. The plants tested were angico (Anadenanthera colubrina), algaroba (Prosopis juliflora), espinheiro (Acacia glomerosa), juazeiro (Ziziphus joazeiro) and soybean meal, which had crude protein values of $22,516,0,22,0,19,0$ and $38,0 \%$, respectively. Samples $(60 \mathrm{mg})$ were incubated with McDougal $(8 \mathrm{ml})$ and inoculated ruminal fluid $(2 \mathrm{ml})$. Aliquots ( $1 \mathrm{ml}$ ) were taking after $0,6,12,24,36$ and 48 hours for analysis of ammonia, soluble protein and microbial protein. Soybean meal and the algaroba showed larger ammonia production and concentration of soluble protein compared to the other treatments. Soybean meal also displayed higher values for microbial protein. The treatment with angico was the one that displayed closed values towards soybean in regard to microbial protein, in spite of showing lesser ammonia production. The largest value of potential degradability $66,47 \%$, was observed for the treatment with soybean meal, followed by the algaroba $46,27 \%$ and of the angico 45,20 . Very low degradability was observed for the espinheiro and juazeiro, 19,16 e16,63\%, respectively. Among the studied plants the angico and the algaroba were better sources of protein.

Key-words: algaroba, angico, espinheiro, juazeiro.

\section{Introdução}

A caatinga, vegetação predominante na região semiárida do Nordeste brasileiro, ocupa uma área de aproximadamente $900.000 \mathrm{~km}^{2}$, cerca de $10 \%$ do território nacional, constituindo-se na mais importante fonte de alimentação para os rebanhos desta região, participando em até $90 \%$ da dieta de caprinos e ovinos (GONZAGA NETO et al, 2001). A alimentação e exploração animal nessa região encontra barreiras para seu desenvolvimento, devido às diversidades climáticas. Na estação seca, as altas temperaturas e baixos índices pluviométricos, prejudicam a produção de alimento para os rebanhos (STEIN, 2002; ARAÚJO et al. 2004). Em contrapartida, no período favorável tem-se boa disponibilidade de forragens através da rebrota das leguminosas.

Muitas destas espécies de leguminosas apresentam elevado valor de proteína bruta; entretanto, sua digestibilidade pode ser baixa, devido à presença de fatores antinutricionais, principalmente o tanino (NOZELLA, 2001; ARAÚJO et al. 2002; ZANINE et al. 2005). A possibilidade de utilização de algumas espécies do estrato arbóreo, abundantes nas épocas chuvosas e com elevado potencial para produção de fenos, justifica estudos mais criteriosos sobre a disponibilidade de seus nutrientes, principalmente a proteína bruta. A degradabilidade da proteína dos alimentos pode ser estimada por técnica in vitro, em que bactérias ruminais 
são incubadas com adição de fontes protéicas, sendo a degradabilidade destas fontes obtida pela relação entre as fontes de nitrogênio existentes no meio de incubação (proteína solúvel, proteína microbiana e amônia) e o nitrogênio total do alimento.

No sentido de explorar e conservar o excedente de forragem disponível, deve-se selecionar as espécies que melhor se prestam para o processo e que apresenta as características forrageiras desejáveis. Poucos trabalhos, entretanto, foram até então realizados objetivando avaliar o potencial forrageiro das espécies vegetais que compõem a caatinga. Nesse contexto, conhecer o valor nutritivo das espécies avaliadas é de extrema importância no processo de seleção das forrageiras.

Por isso, o objetivo deste trabalho foi avaliar a degradabilidade in vitro da proteína de espécies arbóreas do semi-árido brasileiro.

\section{Material e Métodos}

O experimento foi realizado no Laboratório de Microbiologia de Anaeróbios, Departamento de Microbiologia da Universidade Federal de Viçosa. O líquido de rúmen utilizado com o inóculo foi coletado de um bovino fistulado, alimentado com silagem de milho e alojado no Laboratório de Animais do Departamento de Zootecnia. O líquido ruminal foi coletado pela manhã, com o pH em torno da neutralidade, filtrado em quatro camadas de gaze, acondicionado em garrafa térmica, com fechamento hermético, e transportado para o laboratório, onde o $\mathrm{pH}$ foi determinado antes do frasco ser incubado em banho-maria a $39^{\circ} \mathrm{C}$. Após as partículas alimentares flutuarem e os protozoários sedimentarem, foi obtido o líquido da fase mediana do frasco, sendo este utilizado como inóculo. A solução tampão de McDougall, utilizada nas incubações, constituiu-se de $9,80 \mathrm{~g}$ de $\mathrm{NaHCO}_{3} ; 4,65 \mathrm{~g}$ de $\mathrm{Na}_{2} \mathrm{HPO}_{4}{ }^{*} 2 \mathrm{H}_{2} \mathrm{O} ; 0,57 \mathrm{~g}$ de $\mathrm{KCl} ; 0,12 \mathrm{~g}$ de $\mathrm{MgSO}_{4}{ }^{*} 7 \mathrm{H}_{2} \mathrm{O}$ e $0,04 \mathrm{~g}$ de $\mathrm{CaCl}_{2}$, diluídos com água destilada até o volume de $1.000 \mathrm{ml}$, e completado com $0,275 \mathrm{~g}$ de glicose.

Foram testadas cinco fontes de nitrogênio: algaroba (Prosopis juliflora), angico (Anadenanthera colubrine), espinheiro (Acacia glomerosa), juazeiro (Ziziphus joazeiro) (FIGURA 1) e farelo de soja, que continham respectivamente, $16 ; 22,5 ; 22 ; 19$ e $38 \%$ de proteína bruta com base na matéria seca. As plantas foram coletadas no município de Bom Jesus da Lapa - BA, localizado na latitude de $13^{\circ} 15^{\prime}$ '18" Sul, longitude $43^{\circ}$ 25' 05 " Oeste. O período chuvoso é de outubro a fevereiro com precipitação média, nos últimos cinco anos, de $700 \mathrm{~mm}$. Efetuou-se uma amostragem composta das folhas, em três localidades do município. De cada amostra composta foram retiradas amostras simples para as avaliações. O farelo de soja foi incluindo como controle, devido a sua digestibilidade ser conhecida.

FIGURA 1 - ANGICO (Anadenanthera colubrine) (A), ESPINHEIRO (Acacia glomerosa) (B), JUAZEIRO (Ziziphus joazeiro) (C), ALGAROBA (Prosopis juliflora) (D).
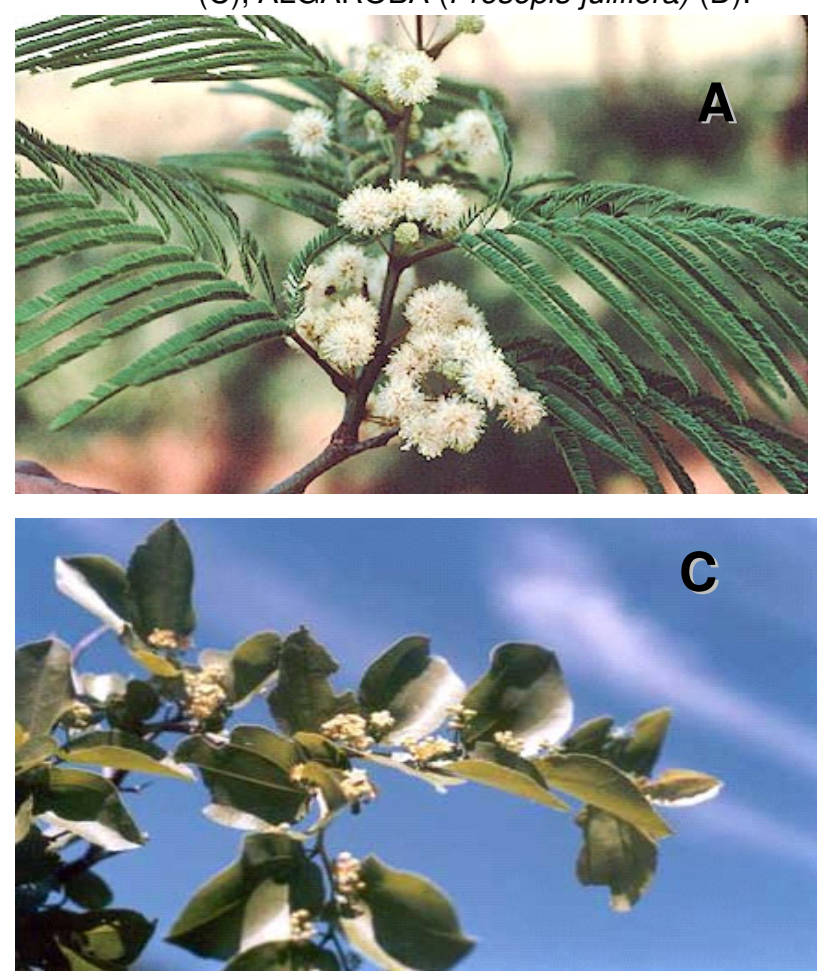
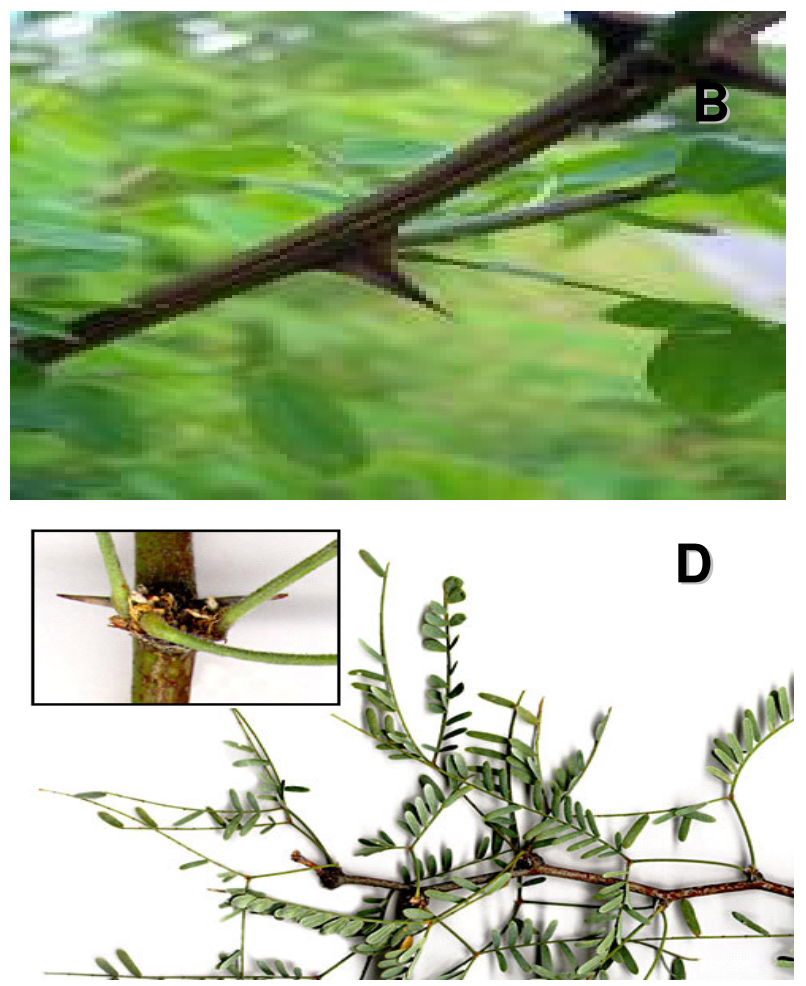
Degradabilidade in vitro da proteína de espécies arbóreas do semi-árido brasileiro

As incubações foram realizadas em frascos de vidro de $30 \mathrm{ml}$, hermeticamente fechados, contendo $8,0 \mathrm{ml}$ de tampão de McDougall, e 2,0 ml de inóculo. Os alimentos foram adicionados de forma que todos os tratamentos apresentassem $60 \mathrm{mg}$ de proteína nos meios de incubação. Os frascos foram saturados com dióxido de carbono e incubados à temperatura de $39^{\circ} \mathrm{C}$, por 48 horas. Coletaram-se amostras de $1,0 \mathrm{ml}$ de material incubado para determinação de amônia, proteína microbiana e proteína solúvel nos tempos 0 , $6,12,24,36$ e 48 horas, a partir do início das incubações. As amostras foram centrifugadas em tubos eppendorf de $1,5 \mathrm{~mL}$ a $12.000 \mathrm{rpm}$ por $10 \mathrm{~min}$, onde o sobrenadante foi transferido para um novo tubo eppendorf e congelado para posterior análise de amônia e proteína solúvel. Os sedimentos advindos da centrifugação foram ressuspensos em solução salina $(\mathrm{NaCl}, 0,9 \%)$ e centrifugados a $12.000 \mathrm{rpm}$ por 10 minutos, duas vezes consecutivas sendo, por último, ressuspensos em água destilada até o volume de 0,6 $\mathrm{mL}$. Após a homogeneização, as amostras foram congeladas para posteriores análises de proteína microbiana. A análise de amônia foi feita através do método colorimétrico de CHANEY e MARBARCH (1962) e as análises de proteína solúvel e microbiana pelo método de LOWRY et al. (1951).

Para obter a curva de degradabilidade potencial da proteína (DP), determinou-se a proporção do nitrogênio solubilizado no meio de cultura ( $\mathrm{N}$-amônia, $\mathrm{N}$-proteína solúvel e N-proteína microbiana), após descontar o nitrogênio presente originalmente no meio contendo líquido ruminal (N-LR Oh), em relação à quantidade total de nitrogênio do alimento incubado (N-alimento) (OLIVEIRA et al. 2004). A fórmula utilizada no cálculo da degradabilidade potencial é apresentada a seguir:

$$
\mathrm{DP}(\%)=\frac{(\mathrm{N} N H 3+\mathrm{N} \text {-proteína solúvel }+\mathrm{N} \text {-proteína microbiana })-\left(\mathrm{N}-\mathrm{LR} \mathrm{Oh}^{*}\right)}{(\mathrm{N} \text {-alimento })} \times 100
$$

*nitrogênio líquido ruminal no tempo zero

O experimento foi analisado em delineamento inteiramente casualizado, com três repetições por tratamento. Os tratamentos tiveram as médias das amostras de 48 horas de incubação, comparadas pelo teste de Tukey a $5 \%$ de probabilidade, utilizando-se o programa SAEG versão 8.0 (UFV, 1999).

\section{Resultados e Discussões}

Nas FIGURAS 2 e 3 podem ser observadas as variações, ao longo do tempo, da produção de amônia e das concentrações de proteína solúvel e microbiana. ATABELA 1 apresenta os valores de produção de amônia, concentrações de proteína solúvel e microbiana, e degradabilidade potencial da proteína após 48 horas de incubação. O farelo de soja e a algaroba proporcionaram maior produção de amônia e concentração de proteína solúvel em relação aos outros alimentos, ao longo da incubação. O farelo de soja, revelou, ainda, maior concentração de proteína microbiana no meio. Por sua vez, o angico apresentou ao longo da incubação, a menor produção de amônia, favorecendo um maior acúmulo de proteína solúvel no meio. Entretanto, a menor produção de amônia, não afetou a síntese microbiana e a concentração de proteína no meio com angico, sendo semelhante àquelas obtidas no meio com farelo de soja.

O juazeiro e o espinheiro apresentaram as menores concentrações de proteína solúvel e microbiana e produção de amônia, sendo que o juazeiro teve a menor concentração de proteína solúvel no meio, e o espinheiro a menor produção de amônia, explicando o fato desses apresentarem a menor concentração de proteína microbiana. Estes resultados demonstram que o angico se destacou entre as espécies estudadas, com relação ao aproveitamento da proteína pelos microrganismos do rúmen, principalmente pelos valores de proteína microbiana próximos aos observados para o farelo de soja.

As leguminosas arbóreas e arbustivas são fontes alternativas e baratas de proteína para a produção animal (GUTTERIDGE, 1990;ARGEL e MAASS, 1995). Todavia é necessário verificar o aproveitamento desta fração protéica em nível ruminal. NOZELLA (2001) avaliando plantas dos estratos herbáceo e arbóreo do semi-árido, pôde verificar diferenças na síntese microbiana, notadamente entre as espécies dos dois diferentes estratos. Com relação às plantas do estrato arbóreo, este autor observou, por meio da técnica de produção de gás in vitro, fase lag semelhante à observada no presente trabalho, por meio da medição da proteína microbiana.

A fonte de alimento influenciou a degradabilidade da proteína, registrando-se o maior valor observado para o farelo de soja $(66,47 \%)$, valor este, próximo àqueles apresentados pelo NRC (1989). Já entre as leguminosas, a algaroba e o angico, foram as que apresentaram maior degradabilidade potencial, com valores de 46, 27 e 45,2\%, respectivamente. Isso, possivelmente, ocorreu pela maior solubilização da proteína do alimento no meio, podendo explicar a baixa degradabilidade da proteína do espinheiro e do juazeiro, respectivamente, 19,16 e $16,63 \%$.

As dicotiledôneas, notadamente, as leguminosas apresentam alta concentração de tanino, que estão negativamente relacionados com a digestibilidade da proteína. Segundo SGARBIERI (1996), os taninos podem formar ligações covalentes com alguns grupos funcionais das proteínas, principalmente os grupos sulfidrílicos da cisteína e da lisina, indisponibilizandoas. Assim, os alimentos com degradabilidade mais baixa (espinheiro e juazeiro) podem ter sofrido efeito de uma possível concentração elevada de tanino. 
FIGURA 2 - CONCENTRAÇÃO DE AMÔNIA $\left(\mathrm{NH}_{3}\right)$ AO LONGO DE 48 HORAS DE FERMENTAÇÃO, POR MICRORGANISMOS RUMINAIS, EM MEIOS DE CULTURA CONTENDO FARELO DE SOJA; ANGICO; ESPINHEIRO; JUAZEIRO E ALGAROBA. VIÇOSA-MG.

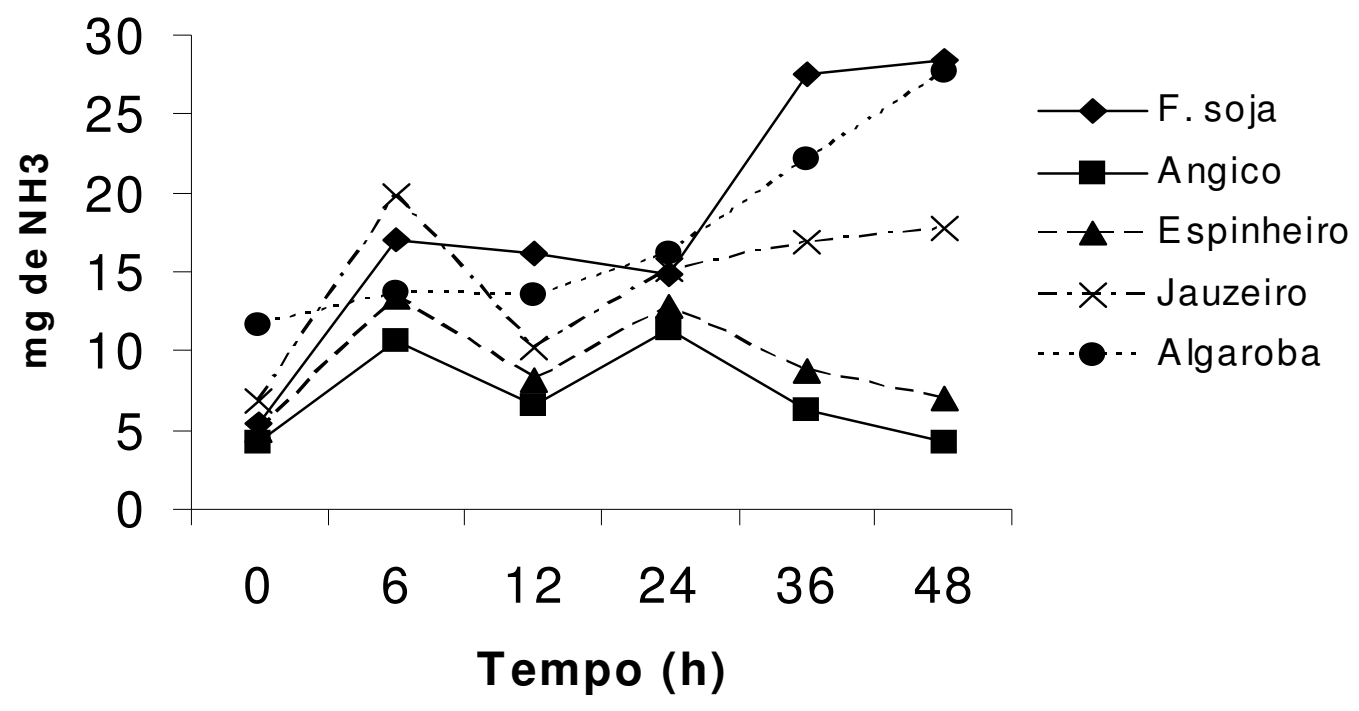

FIGURA 3 - PROTEÍNA SOLÚVEL (PS) AO LONGO DE 48 HORAS DE FERMENTAÇÃO, POR MICRORGANISMOS RUMINAIS, EM MEIOS DE CULTURA CONTENDO FARELO DE SOJA; ANGICO; ESPINHEIRO; JUAZEIRO E ALGAROBA. VIÇOSA-MG.

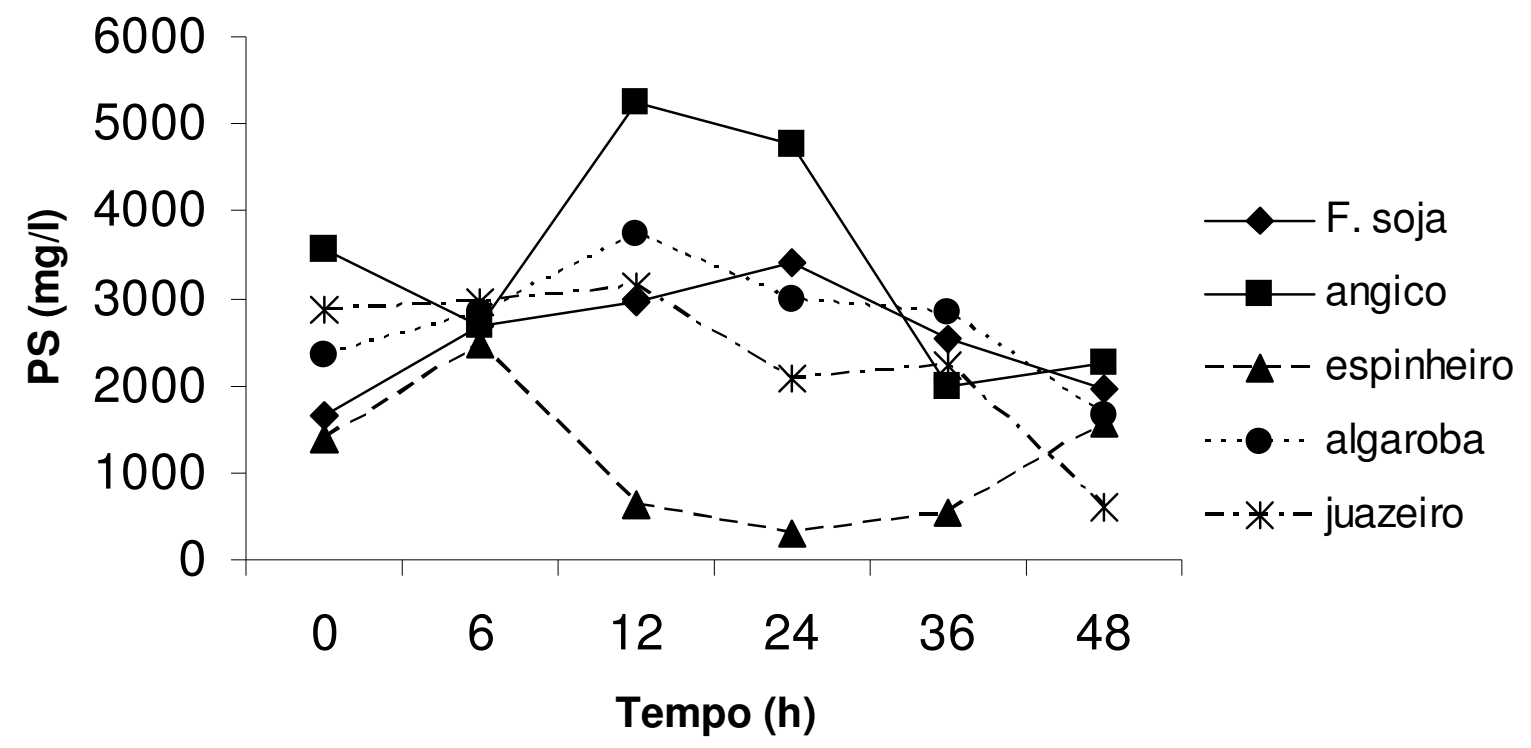



RUMINAIS, EM MEIOS DE CULTURA CONTENDO FARELO DE SOJA; ANGICO; ESPINHEIRO; JUAZEIRO E ALGAROBA.

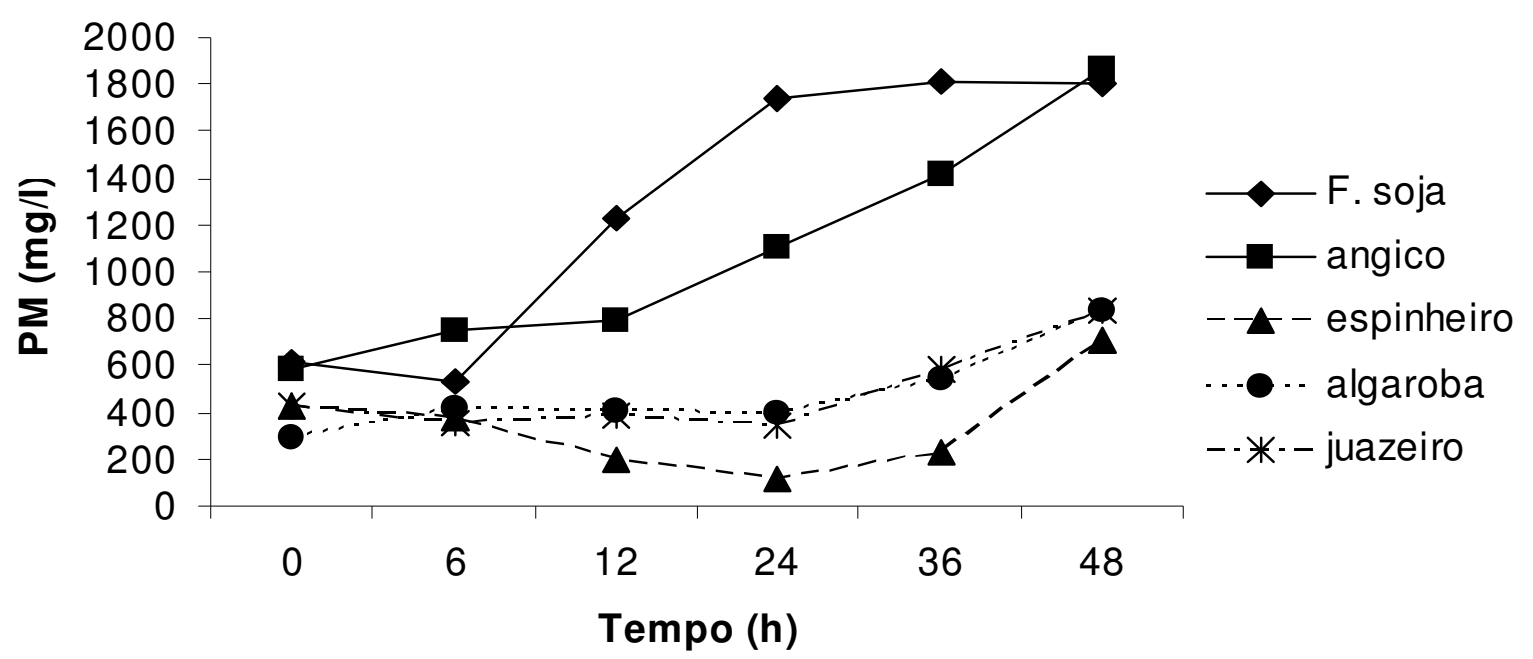

TABELA 1 - PRODUÇÃO DE AMÔNIA, CONCENTRAÇÃO DE PROTEÍNA MICROBIANA E PROTEÍNA SOLÚVEL E DEGRADABILIDADE POTENCIAL DA PROTEÍNA DE DIFERENTES FONTES DE NITROGÊNIO. VIÇOSA-MG

\begin{tabular}{lllllll}
\hline \multicolumn{7}{c}{ Fontes de nitrogênio } \\
\hline Parâmetros & F. soja & Angico & Espinheiro & Juazeiro & Algaroba & CV \% \\
\hline Amônia, mg/dL & $28,34 \mathrm{a}$ & $4,16 \mathrm{~d}$ & $6,99 \mathrm{c}$ & $17,77 \mathrm{~b}$ & $27,74 \mathrm{a}$ & 6,25 \\
Proteína solúvel, $\mathrm{mg} / \mathrm{L}$ & $1,972 \mathrm{ab}$ & $2,248 \mathrm{a}$ & $1.556 \mathrm{~b}$ & $610 \mathrm{c}$ & $1.761 \mathrm{ab}$ & 9,73 \\
Proteína microbiana, $\mathrm{mg} / \mathrm{L}$ & $1,801 \mathrm{a}$ & $1,760 \mathrm{a}$ & $713 \mathrm{~b}$ & $833 \mathrm{~b}$ & $837 \mathrm{~b}$ & 16,85 \\
Degradabilidade, \% & $66,47 \mathrm{a}$ & $45,20 \mathrm{~b}$ & $19,16 \mathrm{c}$ & $16,63 \mathrm{c}$ & $46,27 \mathrm{~b}$ & 10,72 \\
\hline
\end{tabular}

Médias seguidas pela mesma letra na mesma coluna não diferem, estatisticamente, pelo teste de Tukey, $5 \%$ de probabilidade.

NOZELLA (2001) verificou correlação negativa entre a presença de tanino e a síntese microbiana em plantas da região semi-árida, observando maiores valores de tanino e menores crescimentos microbianos nas leguminosas arbóreas. Igualmente concluiu que as plantas com concentrações mais elevadas de tanino apresentaram menor degradabilidade da matéria seca. Valores de tanino de $138,4,204,1$ e $160,0 \mathrm{~g} / \mathrm{kg}$ MS foram observados para o angico, aroeira e jurema-preta, respectivamente, enquanto que para as espécies herbáceas malva-branca, feijão-bravo e mela-bode, foram observados valores de 74,60, 26,02 e 21,69, respectivamente.

Provavelmente os baixos valores de degradabilidade ruminal da proteína do juazeiro e do espinheiro, devem-se à presença de fatores antinutricionais. Por outro lado, deve-se levar em conta de os compostos fenólicos afetam a degradabilidade ruminal da proteína. Outros estudos devem ser realizados para avaliar a digestão pósruminal, com vistas às determinações do real aproveitamento deste nutriente pelos ruminantes.
Apesar dos valores de degradabilidade serem inferiores aos observados para o farelo de soja, o angico e a algaroba destacaram-se entre as plantas estudadas, devendo-se considerar a sua ocorrência natural e abundante, bem como a possibilidade de utilização na alimentação animal. Na região Nordeste do Brasil áreas de bosques formadas por angico, algaroba e outras espécies arbóreas, poderiam fornecer grandes quantidades de alimento, principalmente na forma de feno para serem utilizados na época das secas. Mais trabalhos devem ser conduzidos para avaliar o potencial destas espécies como fonte de alimentação para ruminantes.

\section{Conclusão}

Dentre as leguminosas avaliadas, a algaroba e o angico apresentam-se como melhor fonte de proteína para ruminantes, considerando-se os maiores valores de degradabilidade potencial, a maior solubilização da proteína e a mais elevada síntese de proteína microbiana. 


\section{Referências}

ARAÚJO FILHO, J.A.; CARVALHO, F.C.; GARCIA, R. SOUSA, R.A. Efeitos da manipulação da vegetação lenhosa sobre a produção e compartimntalização da fitomassa pastável de uma caatinga sucessional. Revista Brasileira de Zootecnia, v.31, n.1, p.11-19, 2002.

ARAÚJO, G.G.L.; MOREIRA, J.N.; FERREIRA, M.A.; TURCO, S.H.N.; SOCORRO, E.P. Consumo voluntário e desempenho de ovinos submetidos a dietas contendo diferentes níveis de feno de maniçoba. Revista Ciência Agronômica, v. 35, n.1, p. 123-130, 2004.

ARGEL, P.J.; MAASS, B. Evaluación y adaptación de leguminosas arbustivas em suelos ácidos infertiles de América tropical. In: EVANS, D.O.; SZOTT, L.T. (eds.). Nitrogen Fixing Trees for Acid Soils, Turrialba, Costa Rica. Nitrogen Fixing Tree Research Reports Special Issue, p. 215-227, 1995.

CHANEY, A.L.; MARBACH, E.P. Modified reagents for determination of urea and ammonia. Clinical Chemistry, v.8, p.130-132, 1962.

GONZAGA NETO, S.; BATISTA, A.M.V.; CARVALHO F.F.R.; MARTÍNEZ R.L.V.; BARBOSA, J.E.A.S.; SILVA, E.O. Composição Bromatológica, Consumo e Digestibilidade In Vivo de Dietas com Diferentes Níveis de Feno de Catingueira (Caesalpinea bracteosa), Fornecidas para Ovinos Morada Nova. Revista Brasileira de Zootecnia, n. 30, p. 553-562, 2001.

GUTTERIDGE, R.C. Agronomic evaluation of tree and shrub species in southeast Quensland. Tropical Grasslands, v. 24, n. 1, p. 29-34, 1990.

LOWRY, O.H.; ROSEBROUGH, N.J.; FARR, A.L. et al. Protein measurement with the Folin phenol reagent. Journal of Biological Chemistry, v.193, p.265-275, 1951.
NATIONAL RESEARCH COUNCIL-NRC. National Academic Press, $6^{\text {th }}$. Ed. Washington, 1989, 100p.

NOZELLA, E.F. Determinação de taninos em plantas com potencial forrageiro para ruminantes. Piracicaba, 2001. Dissertação (Mestrado) - Escola Superior de Agricultura Luiz de Queiroz/Universidade de São Paulo, 58p. 2001.

OLIVEIRA, J. S.; LANA, R. P.; BORGES, A. C.; QUEIROZ, A. C.; ALMEIDA, I. C. Efeito da monensina e extrato de própolis sobre a produção e amônia e degradabilidade in vitro da proteína bruta de diferentes fontes de nitrogênio. Revista Brasileira de Zootecnia. v. 33, n. 2, p. 504-510, 2004.

SGARBIERI, V.C. Proteínas em alimentos protéicos: propriedades-degradaçõesmodificações. Varela, cap.5: Deterioração e modificações químicas, físicas e enzimáticas de proteínas São Paulo, 1996, 87p.

STEIN, R.B.S. Avaliação de métodos para determinação da digestibilidade aparente utilizando farelo de vagem de algaroba (Prosopis Juliflora (Swartz) D.C.) em eqüinos. Piracinunga, 2002. Dissertação (Mestrado), Faculdade de Zootecnia e Engenharia de alimentos/Universidade de São Paulo, $86 \mathrm{p}$.

UNIVERSIDADE FEDERAL DE VIÇOSA. Sistema de análises estatísticas e genéticas - SAEG. Viçosa: Universidade Federal de Viçosa. Manual do usuário, (versão 8.0), 1999, 138 p.

ZANINE, A.M.; SANTOS, E.M.; FERREIRA, D.J.; ALMEIDA, J.C.; DE, MACEDO JÚNIOR, G.L.; OLIVEIRA, J.S. Composição bromatológica de leguminosas do semiárido brasileiro. Livestock Research for Rural Development. v. 17, p.1-9, 2005.

Recebido para publicação: $\quad$ 12/01/2006 Aprovado: 